\title{
Sosiaalihuollon asiakasasiakirjarakenteiden katselmointi
}

\author{
Erja Ailio YTM, Niina Häkälä YTM, Jarmo Kärki VTM
}

Terveyden ja hyvinvoinnin laitos (THL), Helsinki, Finland

Erja Ailio, Terveyden ja hyvinvoinnin laitos (THL), PL 30, 00271 Helsinki, FINLAND. Sähköposti: erja.ailio@thl.fi

\section{Tiivistelmä}

Näkemys sosiaalihuollon keskeisestä tietopääomasta tulee luoda yhdessä sosiaalihuollon asiantuntijoiden kanssa. Sosiaalihuollon asiakastietomallia, joka perustuu sosiaalihuollon ammattilaisten kuvaamiin tietotarpeisiin, kehitetään osana sosiaalihuollon valtakunnallisten tietojärjestelmäpalvelujen ja määrämuotoisen kirjaamisen toimeenpanohanketta (Kansa-hanke). Vuosina 2013-2015 sosiaalihuollon ammattilaiset katselmoivat kaikki sosiaalihuollon asiakastietomalliin sisältyvät asiakasasiakirjarakenteet. Katselmointiin osallistuneet sosiaalihuollon ammattilaiset olivat eri puolilta Suomea ja he käyttivät erilaisia tietojärjestelmiä. Katselmoijat arvioivat asiakasasiakirjarakenteiden riittävyyttä ja tarpeellisuutta. Asiakirjarakenteen yksittäisten tietojen osalta arviointikriteereitä olivat muun muassa tiedon tarpeellisuus, tiedon sijainti oikeassa asiakirjassa tai oikeassa kohdassa asiakirjaa sekä tiedon esitysmuodon oikeellisuus. Asiakirjarakenteet keräsivät yli 2000 kommenttia, ja eniten kommentoitiin asiakastyön kannalta keskeisiä, sisällöltään laajoja asiakirjarakenteita kuten palvelutarpeen arvioita ja suunnitelmia. Artikkelissa esitetyt tulokset perustuvat pääasiassa konsultin tekemään tulosten tiivistelmätaulukkoon, joka oli laadittu tulosten yhteenvetoa ja esittelyä varten. Saadun katselmointipalautteen perusteella asiakastietomallista poistettiin useita asiakirjarakenteita, esimerkiksi asiakirjarakenteita, joiden tarkoituksena oli arvioida suunnitelmien toteutumista. Katselmointipalautteen perusteella myös vähennettiin useiden asiakirjojen rakenteisuutta, lisättiin mahdollisuutta narratiiviseen dokumentointiin ja tehtiin myös monia muita pienempiä korjauksia ja muutoksia. Systemaattinen palautteen kerääminen ja sen käsittely on tehokas keino asiakirjarakenteiden laadun varmistamiseksi ja parantamiseksi. Haasteita tulosten tulkintaan ja konsensuksen löytämiseen tuo se, että ammattilaisten toimintaympäristö, käytössä oleva asiakastietojärjestelmä sekä totuttu kirjaamistapa vaikuttavat näkemyksiin siitä, millaisia asiakirjarakenteiden tulisi olla ja millaisia tietoja asiakastyössä tarvitaan. Mahdollisimman selkeä esitysmuoto katselmoitaville tietorakenteille, esimerkiksi asiakastietojärjestelmää jäljittelevän käyttöliittymän avulla, parantaisi tietorakenteiden ymmärrettävyyttä ja niistä annetun palautteen laatua. Paitsi tietorakenteita myös tietojärjestelmien käytettävyyttä ja muita ominaisuuksia tulisi kehittää yhdessä sosiaalihuollon ammattilaisten kanssa.

Avainsanat: sosiaalihuolto, asiakasasiakirja, katselmointi, tietomalli, määrämuotoinen kirjaaminen 


\section{Abstract}

The decision about the relevant information in social care should be made in co-operation with the social care professionals. That is why the data model of Finnish social welfare was evaluated by the social care professionals between 2013 and 2015. The professionals came all over Finland. They evaluated the quality of the client document structures in the data model. They also evaluated the details in every client document structure, for example the necessity, the correct location and the correct data type of each data field. Altogether over 2000 comments were given. The results in this article are based on the summary table which was made by the consultant. Most of the comments concerned those document structures which were extensive by their content and essential in client work, for example the assessments of service need and the client plans. Based on the feedback several client document structures were removed, the data fields for narrative documentation were increased, the data fields for structured documentation were decreased and several minor changes were made. Collecting and analysing feedback systematically is an efficient way to enhance and to confirm the quality of data structures. Challenging is that the operational environment, the client data system used, and the habit of documentation have a significant impact on professionals' views about the relevant information and data structures. When collecting feedback, the presentation of the data structures should be as understandable as possible; this could be achieved for example by simulating client data system interfaces. This could have a positive effect on the quality of the feedback. In addition to data structures also the other properties of the information systems should be created in co-operation with the social care professionals.

Keywords: social welfare, client document, evaluation, data model, standardised documentation

\section{Johdanto}

Osana sosiaalihuollon valtakunnallisten tietojärjestelmäpalvelujen (myöh. Kanta-palvelut) ja määrämuotoisen kirjaamisen toimeenpanohanketta (Kansa-hanke) kehitetään sosiaalihuollon asiakastietomallia, joka sisältää yli 200 asiakasasiakirjan rakenteet. Sosiaalihuollon Kanta-palveluiden käyttöönoton laajentuessa asiakastietomallilla tulee olemaan merkittävä vaikutus myös sosiaalihuollon ammattilaisten käyttämiin asiakastietojärjestelmiin. Tietomallin kehittämisen tavoitteena on luoda yhteinen näkemys sosiaalihuollon keskeisestä tietopääomasta sekä helpottaa asiakasta koskevan informaation löytämistä, välittämistä ja hallintaa kansallisesti. [1,2] Yhteistä näkemystä keskeisestä tietopääomasta ei voida luoda tiedonhallinnan ammattilaisten kesken ilman sosiaalihuollon asiakastyötä tekevien ja sosiaalihuoltoa kehittävien ja tutkivien asiantuntijoiden merkittävää työpanosta.

Tietojärjestelmien suunnittelussa on keskeistä sen tiedon kuvaaminen, jota organisaatio toiminnassaan tarvitsee. Sosiaalityön tutkijat ovat aiheellisesti pohtineet, miten digitaalisuus ja tietojärjestelmien käyttö muuttaa sosiaalityön luonnetta, tiedontuotantoa ja asiakastyötä [3-6]. Tutkijoiden mukaan tietojärjestelmien kehittämisessä tulisi ottaa jo suunnitteluvaiheessa huomioon sosiaalialan toimijoiden, kuten sosiaalityöntekijöiden, ja asiakkaiden tarpeet ja lähtökohdat. Tietojärjestelmillä käsiteltävän tiedon mallintaminen ja suunnittelu, esitettävän tiedon logiikan, muodon, esitystavan ja tallennuspaikan pohdinta, tulee toteuttaa yhdessä tietoa myöhemmin kirjaavien ja käyttävien sosiaalihuollon ammattilaisten kanssa. Haasteena on kuitenkin, että sosiaalihuollon organisatoriset toimintaympäristöt voivat olla keskenään hyvinkin erilaisia ja erikoistuneita eri osa-alueisiin. Tästä johtuen työn sisällöt, kontekstit ja prosessit ovat monimuotoisia. [7] Myöskään sosiaalityön tiedon luonteesta tai tarpeista ei vallitse käyttäjien tai tutkijoiden kesken yksimielisyyttä [8].

Kansainvälisesti on olemassa dokumentoituja esimerkkejä siitä, kuinka tietyn tietojärjestelmän käyttöönottaminen häiritsee sosiaalityön käytäntöjä ja johtaa ammattilaisten kasvavaan tietojärjestelmien vastusta- 
miseen. Epätoivottuja lopputuloksia ovat olleet esimerkiksi tärkeiden ratkaisujen tekemisen vaikeutuminen ja viivästyminen, prioriteettien vääristyminen ja ammattilaisten tietojärjestelmien käyttöön kehittämät erilaiset kiertotiet. [8,9]

Yhteistä tutkijoiden erilaisille näkemyksille ja tutkimuksille kuitenkin näyttäisi olevan, että tietojärjestelmien käyttöönoton onnistumisen todennäköisyys kasvaa, jos sen rakentamisessa on pystytty hyödyntämään sosiaalihuollon ammattilaisten itse määrittelemää merkityksellistä tietoa ja heidän työkäytäntöjensä tuntemista. Sen määritteleminen mitä, miksi, kuinka ja kenen toimesta tietoa tulee tallentaa, on monimutkainen ja haastava tehtävä. Se olisi kuitenkin tehtävä huolellisesti ja ennen kaikkea yhteistyössä asiakastyötä tekevien sosiaalihuollon ammattilaisten kanssa. [7-11.]

Sosiaalihuollon ammattilaiset ja asiantuntijat ovat olleet erilaisissa rooleissa mukana sosiaalihuollon asiakastietomallin kehittämisen eri vaiheissa. Asiakastietomallin tietosisällöt perustuvat Terveyden ja hyvinvoinnin laitoksen (aiemmin Stakes) vuosina 2006-2011 toteuttamiin sosiaalipalvelujen tietotarpeiden kartoituksiin. Niissä kuvattiin palvelukohtaisia asiakastietoja, joita eri sosiaalipalvelujen järjestämisessä ja toteuttamisessa tarvitaan. Kuvaukset tehtiin sosiaalihuollon ja tietotekniikan asiantuntijoiden tiiviissä yhteistyössä, jota leimasi asiantuntijoiden keskinäinen dialogi ja jatkuva toisiltaan oppiminen sekä yhteisen kielen etsintä. [1] Sosiaalihuollon ammattilaiset ovat osallistuneet myös tietorakenteiden pilotoimiseen osana erilaisia valtionavustushankkeita. Sosiaalihuollon asiakasasiakirjojen ja luokitusten asiantuntijaryhmä on vuosina 2012-2016 osallistunut sosiaalipalveluissa tarvittavien asiakasasiakirjojen, luokitusten ja sanastojen kehittämiseen ja linjannut sitä. Sosiaalihuollon ammattilaiset myös osallistuivat sosiaalihuollon asiakastietomalliin sisältyvien asiakasasiakirjarakenteiden katselmointiin, josta tässä artikkelissa kerrotaan tarkemmin.

Tämän artikkelin tarkoituksena on esitellä sosiaalihuolIon asiakastietomalliin sisältyvien asiakasasiakirjarakenteiden katselmoinnin organisointia ja tuloksia. Artikkelissa esitellyt tulokset perustuvat pääasiassa konsultin tekemään tulosten tiivistelmätaulukkoon, joka oli laa- dittu tulosten yhteenvetoa ja esittelyä varten. Artikkelissa kuvataan ensin sosiaalihuollon asiakasasiakirjarakenteiden katselmointiprojektin tavoitteita ja organisointia. Seuraavassa luvussa kuvataan sosiaalihuollon asiakasasiakirjarakenteiden katselmoinnin tuloksia ja sen jälkeen analysoidaan projektissa saadun palautteen keskeisiä vaikutuksia sosiaalihuollon asiakastietomalliin. Viimeisessä luvussa pohditaan sosiaalihuollon asiakastietomallin kehittämisen haasteita ja tulevaisuuden näkymiä.

\section{Sosiaalihuollon asiakasasiakirjarakenteiden katselmointiprojektin tavoitteet ja organisointi}

Kun asiakastietomallin kehittäminen aloitettiin, keskeisenä lähteenä olivat sosiaalihuollon ammattilaisten kanssa laaditut palvelukohtaiset asiakastietokuvaukset. Kuvausten pohjalta yhtenäistettiin ja mallinnettiin sähköisiä asiakirjarakenteita ja tietokomponentteja. [1] Asiakirjarakenteiden yhtenäistämisellä ja tietokomponenttipohjaisella mallintamisella oli merkittävä vaikutus jokaisen yksittäisen palvelutehtävän ja sosiaalipalvelun asiakirjarakenteisiin. Terveyden ja hyvinvoinnin laitos (THL) halusi varmistaa, että asiakirjarakenteet soveltuvat tehtyjen muutostenkin jälkeen sosiaalihuollon ammattilaisten tekemään asiakastyöhön. Tarkemmin määriteltyinä katselmointiprojektin tavoitteina oli varmistaa sosiaalihuollon asiakasasiakirjarakenteiden sisällöllinen laatu sosiaalipalvelujen järjestämisen ja tuottamisen asiakastyön dokumentoinnin tarpeisiin sekä tunnistaa ja poistaa tietomallista virheitä ja puutteita. Tällä pyrittiin ehkäisemään muun muassa turhia ohjelmistokorjauksia asiakastietomallin käyttöönottovaiheessa. [12]

Edellä kuvatuista syistä THL kilpailutti Sosiaalihuollon asiakastietomallin katselmoinnin suunnittelun ja toteutuksen keväällä 2013. Kilpailutuksen perusteella katselmoinnin toteuttajaksi valikoitui Tieto Finland Oy. Projekti toteutettiin vuosina 2013-2015. Projekti jakautui kolmeen vaiheeseen: suunnitteluvaiheeseen ja kahteen varsinaiseen katselmointivaiheeseen. [12]

Projektin katselmointityölle asetettiin kolme vaatimusta. Ensinnäkin asiakirjamääritykset tuli katselmoida sosiaalihuollon asiakas- ja kehittämistyötä tekevien 
ammattilaisten toimesta. Tällä vaatimuksella pyrittiin poistamaan se riski, että esimerkiksi pelkästään kuntien tiedonhallinnan ammattilaiset olisivat katselmoineet asiakirjarakenteet. Toiseksi kunkin sosiaalipalvelun osalta edellytettiin ylikunnallista katselmointiasiantuntemusta. Tällä vaatimuksella haluttiin varmistaa, ettei katselmointipalaute perustu vain yhden kunnan tai organisaation näkemykseen. Maantieteellisesti katselmointiorganisaatioita oli eri puolilta Suomea niin pääkaupunkiseudulta Inariin kuin Turusta Kouvolaan. Lisäksi edellytettiin vielä käytetystä asiakastietojärjestelmästä riippumatonta katselmointiasiantuntemusta. Edellytyksellä haluttiin varmistaa, etteivät palautteenantajat liiaksi tukeudu ja kuvaa jo jotakin käytössään olevaa asiakastietojärjestelmää. Katselmointiin osallistui muun muassa Pro Consonan, Effican ja Abilitan käyttäjiä, mutta lisäksi mukana oli myös muiden toimittajien sekä kuntien omien asiakastietojärjestelmien käyttäjiä. Osa katselmoijista käytti asiakastyönsä dokumentointiin excel-taulukoita tai organisaation omia muistiinpanopohjia. Kolmantena vaatimuksena edellytettiin, että katselmoijaorganisaatioita tuli olla vähintään kolme kutakin asiakasasiakirjarakennetta kohden. [12]

Katselmoinnin toteuttaja kokosi asiantuntijaverkoston laatimalla aiheesta tiedotteen ja ilmoittautumislinkin, jotka julkaistiin THL:n sosiaalihuollon tiedonhallinnan sivustoilla. Joihinkin organisaatioihin otettiin myös kohdennetusti yhteyttä, jotta kuhunkin asiakasasiakirjakokonaisuuteen saatiin riittävä määrä katselmoijia. Yhteensä 29 eri organisaatiota ilmoittautui katselmointiin mukaan. [12]

Sosiaalihuollon asiakasasiakirjojen aihealueet jaettiin työpaketteihin, joissa oli yhdestä neljään toisiaan lähellä olevaa aihealuetta. Tavoitteena oli, että katselmointiin ilmoittautunut organisaatio katselmoi kaikki siihen työpakettiin kuuluvat asiakasasiakirjarakenteet. [12]

Kussakin katselmointiorganisaatiossa pidettiin aloituspalaveri. Palaverissa katselmoinnin toteuttajaorganisaation konsultti antoi taustatietoa projektista, esitteli katselmointikriteerit ja opasti palautteen antamisessa. Tämän jälkeen kunkin katselmointiorganisaation asiantuntijaryhmä järjestäytyi sisäisesti katselmointia varten ja sopi työskentelyn etenemisestä. Asiantuntijat katselmoivat asiakirjarakenteet, kirjasivat palautteen ja toimittivat sen konsultille. [12]

Katselmoijat arvioivat kunkin asiakirjakokonaisuuden kohdalla asiakasasiakirjarakenteiden riittävyyttä ja tarpeellisuutta. Kunkin asiakirjarakenteen tietotasoiset arviointikriteerit olivat tiedon tarpeellisuus, tiedon sijainti oikeassa asiakirjassa tai oikeassa kohdassa asiakirjaa, tiedon nimeämisen onnistuminen tai otsikoinnin sopivuus, tiedon esitysmuodon oikeellisuus sekä tiedon toistuvuus ja tiedon pakollisuus. [12]

Lopuksi konsultti yhdisti eri organisaatioiden katselmointipalautteet samaan tiedostoon ja lähetti sen vahvistettavaksi kunkin asiantuntijaryhmän yhteyshenkilön kautta. Vahvistuskierroksella oli kaksi tarkoitusta. Ensinnäkin katselmoijat saivat nähtäväkseen muiden antamat palautteet. Ennen kaikkea heiltä kuitenkin odotettiin kannanottoa muiden antamiin kommentteihin joko kannattamalla havaintoa tai antamalla siihen vastakommentti. [12]

Vahvistuskierroksen päätyttyä konsultti viimeisteli katselmointien palautedokumentit, laati tuloksista yhteenvedon esitysmateriaaliin ja esitteli sen sosiaalihuollon asiakasasiakirjojen ja luokitusten asiantuntijatyöryhmälle ja luovutti materiaalit THL:Ile. [12]

\section{Sosiaalihuollon asiakasasiakirjarakenteiden katselmoinnin tulokset}

Katselmoitavana oli yhteensä 25 asiakirjakokonaisuutta, ja ne sisälsivät yhteensä 270 asiakirjarakennetta. Asiakirjarakenteet jakaantuivat eri kokonaisuuksiin siten, että asiakirjoja oli kokonaisuuksissa 1-48. Nämä asiakirjakokonaisuudet olivat pääasiassa sen hetkisen sosiaalipalvelujen luokituksen mukaisesti muodostettuja. Asiakirjojen jaottelu eri kokonaisuuksiin on ehtinyt katselmoinnin jälkeen muuttua, mutta sillä ei ole ollut vaikutusta katselmointipalautteen huomioimiseen. Kommentteja annettiin kaikkiin asiakirjoihin yhteensä 2090. 
Tässä artikkelissa esitellyt tulokset perustuvat pääasiassa konsultin tekemään tulosten tiivistelmätaulukkoon, joka oli laadittu tulosten yhteenvetoa ja esittelyä varten. Tiivistelmätaulukko sisälsi palautteiden lukumäärät asiakirjoittain, asiakirjakokonaisuuksittain ja palautealueittain (tarpeellisuus, otsikko, esitysmuoto, toistuvuus, pakollisuus, tiedon sijainti, esimerkki, muu). Palautetta analysoitaessa havaittiin, että kyseisen yhteenvetotaulukon sisältämät palautteiden lukumäärät eivät kaikilta osin vastanneet varsinaisten palautedokumenttien palautteiden lukumääriä. Erityisesti pakollisuuteen ja toistuvuuteen jätetyissä kommenteissa oli tehty karsintaa niitä laskettaessa yhteen tiivistelmätaulukkoa varten. Tämä on huomioitava tulosten luotettavuutta arvioitaessa.

Taulukkoon 1 on koottu asiakirjakokonaisuuksittain olennaisia tietoja saadusta palautteesta. Taulukossa on asiakirjakokonaisuuksien sisältämien asiakirjarakenteiden määrä sekä niihin tulleen katselmointipalautteen määrä. Koska asiakirjakokonaisuudet sisältävät hyvin vaihtelevan määrän asiakirjarakenteita, on taulukossa esitetty palautteen määrä, joka on jaettu asiakirjarakenteiden määrällä. Lisäksi taulukossa on jokaisen asiakirjakokonaisuuden vähiten ja eniten palautetta saaneen asiakirjarakenteen palautemäärät. Taulukon viimeisessä sarakkeessa on sen asiakirjarakenteen nimi, joka sai eniten palautetta jokaisessa asiakirjakokonaisuudessa. Kuten taulukko osoittaa, katselmointipalautteen määrä vaihteli suuresti asiakirjakokonaisuuksittain. Eniten kommentoitiin lastensuojelun sijais- ja jälkihuollon asiakirjarakenteita, joka oli myös asiakirjamäärältään suurin kokonaisuus. Kun kommenttien määrä suhteutettiin kokonaisuuksissa olevien asiakirjojen määrään, eniten palautetta jätettiin kotoutumisen edistämisen asiakirjoihin. Sen jälkeen suhteellisesti eniten palautetta keräsivät palveluseteliin liittyvät asiakirjarakenteet, toimeentulotuen ja lastensuojelun avohuollon ja vireilletulon asiakirjarakenteet. Virka-apuun liittyviä asiakirjarakenteita ei kommentoitu lainkaan. Myös adoptioneuvonnan asiakirjarakenteet saivat hyvin vähän kommentteja.

Taulukko 1. Katselmoitujen asiakirjarakenteiden määrä, palautteen määrä, palautteen määrä suhteutettuna asiakirjarakenteiden määrään, annetun palautteen vaihteluvälit ja eniten palautetta saanut asiakirjarakenne asiakirjakokonaisuuksittain.

\begin{tabular}{|c|c|c|c|c|c|}
\hline Asiakirjakokonaisuus & $\begin{array}{l}\text { Asiakirja- } \\
\text { rakenteiden } \\
\text { määrä }\end{array}$ & $\begin{array}{l}\text { Palaut- } \\
\text { teen } \\
\text { määrä }\end{array}$ & $\begin{array}{l}\text { Palautteen suh- } \\
\text { teellinen määrä / } \\
\text { asiakirjarakenne }\end{array}$ & $\begin{array}{l}\text { Palautteen mää- } \\
\text { rän vaihteluväli } \\
\text { asiakirjaraken- } \\
\text { teiden välillä }\end{array}$ & $\begin{array}{l}\text { Eniten palautetta saanut } \\
\text { asiakirjarakenne }\end{array}$ \\
\hline Muutoksenhaku & 4 & 13 & 3,3 & $1-7$ & Vastine \\
\hline Toimeentulotuki & 9 & 148 & 16,4 & $1-80$ & Toimeentulotukihakemus \\
\hline Kotoutumisen edistäminen & 6 & 162 & 27 & $1-55$ & $\begin{array}{l}\text { Kotoutumisen alkukartoi- } \\
\text { tus }\end{array}$ \\
\hline $\begin{array}{l}\text { Lastensuojelun vireilletulo ja } \\
\text { avohuolto }\end{array}$ & 12 & 199 & 16,6 & $4-47$ & $\begin{array}{l}\text { Lastensuojelun avohuol- } \\
\text { lon asiakassuunnitelma }\end{array}$ \\
\hline $\begin{array}{l}\text { Lastensuojelun sijais- ja } \\
\text { jälkihuolto }\end{array}$ & 48 & 240 & 5 & $0-59$ & $\begin{array}{l}\text { Päätös lapsen kiireellisen } \\
\text { sijoituksen jatkamisesta }\end{array}$ \\
\hline Sosiaaliasiamiestoiminta & 2 & 27 & 13,5 & $9-18$ & $\begin{array}{l}\text { Sosiaaliasiamiestoimin- } \\
\text { nan palvelutapahtuma- } \\
\text { kertomus }\end{array}$ \\
\hline Sosiaalinen luototus & 16 & 85 & 5,3 & $0-41$ & $\begin{array}{l}\text { Arvio sosiaalisen luoto- } \\
\text { tuksen tarpeesta }\end{array}$ \\
\hline Isyyden selvittäminen & 15 & 71 & 4,7 & $0-18$ & $\begin{array}{l}\text { Isyyden selvittämispöytä- } \\
\text { kirja }\end{array}$ \\
\hline $\begin{array}{l}\text { Lapsen elatusavun vahvis- } \\
\text { taminen }\end{array}$ & 8 & 43 & 5,4 & $3-10$ & $\begin{array}{l}\text { Päätös lapsen elatusso- } \\
\text { pimuksen vahvistamises- } \\
\text { ta }\end{array}$ \\
\hline Lapsen huollon ja tapaamis- & 8 & 42 & 5,3 & $1-15$ & Selvitys tuomioistuimelle \\
\hline
\end{tabular}


lapsen huoltoa koskevassa asiassa

\begin{tabular}{|c|c|c|c|c|}
\hline Virka-apu & 2 & 0 & 0 & \\
\hline $\begin{array}{l}\text { Puolison elatusavun vahvis- } \\
\text { taminen }\end{array}$ & 6 & 24 & 4 & $1-9$ \\
\hline Kasvatus- ja perheneuvonta & 7 & 92 & 13,1 & $4-36$ \\
\hline Perheasioiden sovittelu & 1 & 19 & 19 & \\
\hline Lastensuojelun perhetyö & 4 & 42 & 10,5 & $3-28$ \\
\hline Koulun sosiaalityö & 8 & 41 & 5,1 & $0-12$ \\
\hline Vammaispalvelut & 14 & 110 & 7,9 & $0-31$ \\
\hline $\begin{array}{l}\text { Kehitysvammaisten erityis- } \\
\text { huolto }\end{array}$ & 17 & 90 & 5,3 & $0-25$ \\
\hline $\begin{array}{l}\text { Sosiaalihuoltolain mukaiset } \\
\text { asiakirjat }\end{array}$ & 19 & 233 & 12,3 & $1-97$ \\
\hline Adoptioneuvonta & 21 & 31 & 1,5 & $0-10$ \\
\hline Päihdehuolto & 13 & 80 & 6,2 & $0-35$ \\
\hline $\begin{array}{l}\text { Työttömien työllistymisen } \\
\text { tukeminen }\end{array}$ & 9 & 115 & 12,8 & $1-39$ \\
\hline Kotipalvelut & 13 & 88 & 6,8 & $1-17$ \\
\hline Omaishoidon tuki & 6 & 67 & 11,2 & $1-55$ \\
\hline Palveluseteli & 2 & 28 & 14 & $9-19$ \\
\hline Yhteensä & 270 & 2090 & 7,7 & $0-97$ \\
\hline
\end{tabular}

Sosiaalihuollon palvelutarpeen arvio, toimeentulotukihakemus, päätös lapsen kiireellisen sijoituksen jatkamisesta, kotoutumisen alkukartoitus ja lastensuojelun avohuollon asiakassuunnitelma saivat kaikista asiakirjarakenteista eniten kommentteja. Kaikki nämä asiakirjarakenteet ovat sisällöltään laajoja. Sellaisia asiakirjarakenteita, joihin ei jätetty yhtään kommenttia, oli yhteensä 46. Valtaosa näistä asiakirjarakenteista, joitakin poikkeuksia lukuun ottamatta, oli sisällöltään suppeita eivätkä ne ole asiakastyön tiedontuottamisen kannalta keskeisimpiä asiakirjoja.

Saatua palautetta tarkasteltiin myös asiakirjatyypeittäin. Tarkasteluun otettiin mukaan asiakastyössä yleisimmin käytetyt ja tiedontuotannon kannalta keskeisimmät asiakirjatyypit: suunnitelma, suunnitelman arvio, päätös, hakemus, asiakaskertomus, palvelutarpeen arvio (tai sitä vastaava tilannearvio) ja ilmoitus (tai sitä vastaava yhteydenotto). Myös tässä palautteen määrä suhteutettiin asiakirjarakenteiden määrään.

Ylivoimaisesti eniten palautetta keräsivät palvelutarpeen arviot ja niitä vastaavat tilannearviot (42 kommenttia/asiakirjarakenne). Niitä kommentoitiin moninkertaisesti verrattuna muihin asiakirjatyyppeihin. Palvelutarpeen arviot ovatkin asiakasprosessin kannalta välttämättömiä asiakirjoja, ja ne ovat sisällöiltään laajoja, sosiaalityön ja asiakkaan tilanteen arviointia sisältäviä kokonaisuuksia. Toiseksi eniten kommentoitiin suunnitelmia (15 kommenttia/asiakirjarakenne), joiden merkitys asiakastyössä on hyvin samankaltainen kuin palvelutarpeen arvioiden. Hakemuksiin jätettiin kolmanneksi eniten palautetta (14 kommenttia/asiakirjarakenne). Loput asiakirjatyypit saivat huomattavasti vähemmän ja keskenään suurin piirtein saman verran palautetta $(5,3-6,5$ kommenttia/asiakirjarakenne). 
Kuten aikaisemmin mainittiin, palautetta annettiin yhdeksästä eri aihealueesta. Katselmointiin osallistuneilta pyydettiin näkemyksiä siitä, onko asiakirjassa olevien tietojen kerääminen tarpeetonta ja jos on, niin miksi (tarpeellisuus). Heiltä kysyttiin myös otsikoiden sopivuutta ja sitä, onko tiedot otsikoitu työntekijän ja asiakkaan näkökulmista ymmärrettävästi. Heitä pyydettiin myös tarvittaessa ehdottamaan uutta otsikkoa (otsikko). Kommentteja pyydettiin tiedon esitysmuodon oikeellisuuteen eli siihen, onko asiakirjojen tiedot määritelty kerättäväksi siinä muodossa, joka soveltuu asiakastyöhön parhaiten (esitysmuoto).

Tietojen pakollisuuksia ja toistuvuuksia pyydettiin myös kommentoimaan: onko tietyn tiedon kerääminen välttämätöntä kaikissa asiakastyön tilanteissa, joissa asiakirjaa käytetään, tai onko se ehdollisesti pakollista (pakollisuus) ja tuleeko tietokenttä voida täyttää useampaan kertaan (toistuvuus). Katselmoinnissa pyydettiin lisäks kommentoimaan sitä, sijaitsevatko tiedot asiakirjassa työprosessissa tapahtuvan kirjaamisen ja luettavuuden kannalta mielekkäässä järjestyksessä, ja kuinka järjestystä pitäisi mahdollisesti muuttaa (tiedon sijainti). Palautteenantajille annettiin myös mahdollisuus hankalissa tulkinnoissa tai vaikeissa tilanteissa laatia esimerkkejä tietokentän arvoista eli siitä, mitä tietokenttään voisi kirjoittaa (esimerkki). Lopuksi, kommentteja sai antaa myös muihin kuin edellä mainittuihin kokonaisuuksiin liittyen (muu).

Aihealueittain kommentit jakautuivat niin, että eniten annettiin muu-kategoriaan kuuluvia kommentteja (558 kommenttia). Pääasiassa muu-kategorian kommentit liittyivät siihen, millaisia tarpeellisia tietoja palautteenantajien näkemyksen mukaan asiakirjoista puuttui. Tietojen tarpeellisuutta kommentoitiin toiseksi eniten, siihen liittyviä kommentteja annettiin 530. Otsikoiden sopivuutta kommentoitiin 366 kertaa ja kenttien pakollisuuksia 285 kertaa. Loput kategoriat saivat selvästi vähemmän kommentteja, noin sata kommenttia jokainen, paitsi esimerkki-kategoria, johon liittyviä kommentteja tuli vain 57 .

Kuvassa 1 havainnollistetaan, kuinka saatu palaute jakautuu asiakirjakokonaisuuksittain ja eri palautekategorioittain. Palautteiden määrät on edelleen suhteutettu kokonaisuuksittain katselmoitavana olevien asiakirjarakenteiden määrään. Perheasioiden sovittelun asiakirasiakirjarakenteisiin annettiin suhteellisesti muita enemmän kommentteja tietojen tarpeellisuuteen liittyen, myös kotoutumisen edistämisen ja omaishoidon tuen asiakirjarakenteiden tietojen tarpeellisuutta kommentoitiin runsaasti.

Otsikoihin oli kiinnitetty huomioita erityisesti kotoutumisen edistämisen asiakirjarakenteissa, joihin annettiin otsikoihin liittyvää palautetta moninkertaisesti muihin asiakirjarakenteisiin verrattuna. Palvelusetelin, lastensuojelun vireilletulon ja avohuollon sekä perheasioiden sovittelun asiakirjarakenteisiin annettiin tietojen pakollisuuksiin liittyvää palautetta enemmän kuin muihin asiakirjakokonaisuuksiin. Kategoriaan "muu" kuuluvia kommentteja annettiin eniten koulun sosiaalityön asiakirjarakenteisiin. Sosiaaliasiamiestoiminnan ja perheasioiden sovittelun asiakirjarakenteet saivat myös muita enemmän tämän kategorian palautetta. 


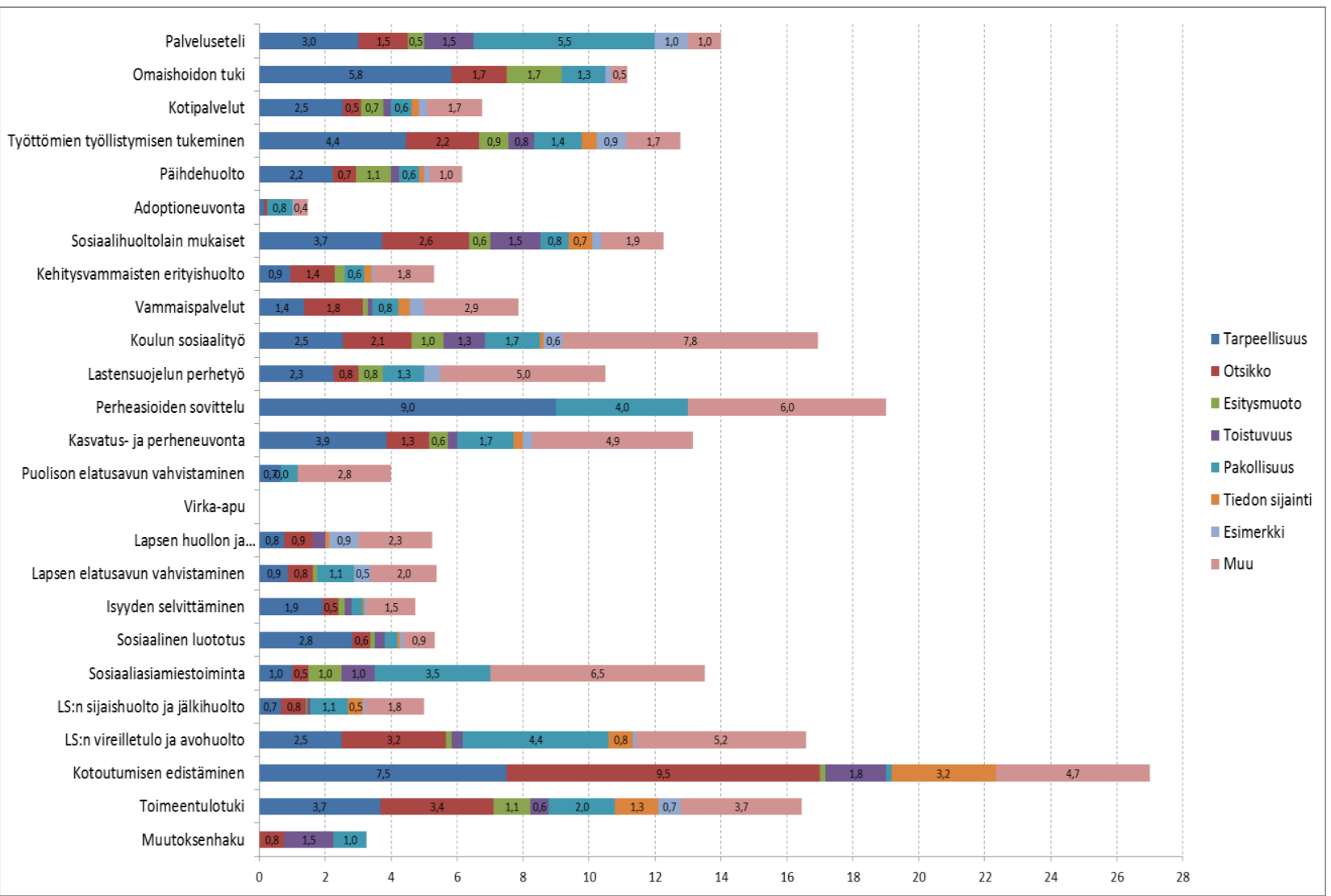

Kuvio 1. Palautteet asiakirjakokonaisuuksittain ja palautekategorioittain, suhteutettuna asiakirjojen määrään.

Tässä luvussa on kuvattu, kuinka annettu palaute on jakautunut eri asiakirjakokonaisuuksien, asiakirjatyyppien ja asiakirjarakenteiden välillä. Analyysin perusteella kommenttien määrällä ei välttämättä kaikissa tapauksissa ollut suoraa yhteyttä siihen, kuinka onnistunut asiakirjarakenne oli. Useissa tapauksissa toki kommenttien suuri määrä kieli siitä, että kyseinen asiakirjarakenne vaatii kehittämistä, mutta kommenttien suuri määrä saattoi liittyä myös siihen, että kyseinen rakenne sisälsi paljon tietokenttiä, sitä pidettiin tärkeänä asiakirjana asiakastyön kannalta, ja sen rakenne ja sisältö poikkesi palautteenantajien organisaatiossa käytössä olevista vastaavista asiakirjoista.

Myöskään kommenttien vähäisyys ei välttämättä tarkoittanut sitä, että asiakirjarakenteeseen oltiin täysin tyytyväisiä eikä siitä löydetty mitään puutteita. Se saattoi merkitä myös sitä, että rakennetta ei osattu kommentoida, koska sitä ei ymmärretty. Palautteen vähäisyys saattoi kertoa siitäkin, että asiakirjarakenteen sisältö oli suppea, ja tietokenttiä, joista palautetta oli mahdollista antaa, oli vain muutamia. Myös ne asiakirjarakenteet, jotka katselmoijat kokivat täysin tarpeettomiksi, saattoivat saada vähän tai ei ollenkaan kommentteja: sisällön kommentointi koettiin turhaksi, koska koko asiakirjaa pidettiin tarpeettomana.

Adoptioneuvonta oli yksi niistä asiakirjakokonaisuuksista, joka sai vain vähän palautetta. Tämä saattoi johtua siitä, että kyseessä on hyvin pieni palvelu, jonka lainsäädäntö on vastikään uudistettu. Lisäksi lakiuudistuksen johdosta tehty päivitys oli tehty hyvin huolellisesti niin, että asiakirjarakenteiden päivitykseen liittyen oli järjestetty monta pienryhmätapaamista alan asiantuntijoiden kanssa. 
Katselmointipalautteen analysointi ja sen vaikutukset sosiaalihuollon asiakastietomalliin

Kun saatu katselmointipalaute esiteltiin sosiaalihuollon asiakasasiakirjojen ja luokitusten asiantuntijaryhmälle, ryhmä otti kantaa paitsi saatuun palautteeseen myös siihen, kuinka se tulisi analysoida. Mikäli palautetta oli vähän ja sen analysointi vaikutti melko yksinkertaiselta, asiantuntijaryhmä päätti, että analyysi voidaan tehdä THL:n asiantuntijoiden virkatyönä. Hieman haastavammassa tapauksessa saatettiin kehottaa konsultoimaan aihealueen asiantuntijoita esimerkiksi joidenkin tiettyjen asiakirjarakenteiden osalta. Mikäli palautetta oli paljon ja sen analysointi vaikutti erityisen haastavalta, asiantuntijaryhmä päätti, että analysoinnin tueksi tulisi perustaa aihealueen ja THL:n asiantuntijoista koostuva pienryhmä. Esimerkiksi lastensuojelun suunnitelmien kehittämiseksi perustettiin oma pienryhmä.

Saatua katselmointipalautetta on analysoitu ja käsitelty vuosien 2015-2016 aikana. Analysointivaiheessa asiakirjarakenteet jaettiin neljään kokonaisuuteen, joka määritteli analysoitavien kokonaisuuksien järjestystä. Perusteena olivat muun muassa palvelun lainsäädännöllinen valmius ja toimintojen vakiintuneisuus kentällä sekä katselmointipalautteiden laatu ja määrä. Paikoin analyysia vaikeutti käynnissä ollut sosiaalihuollon lainsäädännön uudistaminen. Osa saadusta palautteesta, esimerkiksi isyyden selvittämiseen ja osin toimeentulotukeen liittyvä, vanheni lainsäädännön muuttumisen myötä.

Palautteen perusteella tehty analyysi ja muokatut asiakirjarakenteet esiteltiin sosiaalihuollon asiakasasiakirjojen ja luokitusten asiantuntijaryhmälle. Asiantuntijaryhmässä käsiteltiin palautteen perusteella tehdyt muutokset, se miksi osa palautteesta ei johtanut muutoksiin sekä erityisesti analyysin haastavat kohdat, joihin toivottiin asiantuntijaryhmän linjausta. Yksittäisiin asiakirjarakenteisiin kohdistuneet katselmointipalautteet olivat paikoitellen ristiriitaisia, mikä teki palautteen analysoinnista haastavaa ja vaikeutti päätöksentekoa rakenteiden muuttamisesta. Samaa sosiaalipalvelua tarjoavat katselmoijat työskentelevät hyvin erilaisissa toimintaympäristöissä, joissa dokumentointi on keskenään erilaista, ja täten myös näkemykset tietotarpeista ja vaatimukset asiakirjojen sisällöille poikkeavat toisistaan. Palautteen analysoimisessa ja muutospäätösten tekemisessä olikin paikoin turvauduttava kompromisseihin.

Kussakin asiakirjakokonaisuudessa oli omia muutostarpeita, jotka liittyivät spesifisti kyseiseen palveluun tai johonkin tiettyyn asiakirjarakenteeseen. Jotkut muutostarpeet kuitenkin läpäisivät kaikkia tai lähes kaikkia asiakirjakokonaisuuksia. Sosiaalihuollon asiakastietomalli sisälsi ennen katselmointia useita asiakirjarakenteita, joita oli tarkoitus käyttää kyseisen palvelun tarpeesta ilmoittamiseen tai tehdyn ilmoituksen arvioimiseen. Katselmointipalautteessa sosiaalihuollon ammattilaiset hämmästelivät erilaisten ilmoitusten paljoutta. Palautteen perusteella he eivät kaivanneet erillisiä ensiarvio-asiakirjarakenteita tehdyn ilmoituksen arvioimiseen. Sosiaalihuollon asiakasasiakirjojen ja luokitusten asiantuntijaryhmä päätti saadun palautteen perusteella, että erilliset ilmoitusasiakirjojen rakenteet korvataan sosiaalihuollon yhteisellä yhteydenottoasiakirjarakenteella, jolla voi ilmoittaa mistä tahansa sosiaalihuollon tarpeesta ja sen vastinparilla eli asiakirjalla, josta ilmenee mitä yhteydenoton perusteella päätettiin tehdä. Ratkaisu on perusteltu, koska asiakkuuden alkuvaiheessa ei välttämättä tiedetä, mitä palveluja asiakas tarvitsee ja minkä palvelujen piiriin hän lopulta ohjautuu. Tehtyä ratkaisua tukee myös sosiaalihuoltolain muutos, jossa säädettiin yhteydenotosta sosiaalihuoltoon henkilön tuen tarpeen arvioimiseksi [13]. Poikkeuksen tästä linjauksesta tekee lastensuojeluilmoitus, joka jätettiin tietomalliin yleisen yhteydenottoasiakirjarakenteen rinnalle.

Sosiaalihuollon asiakastietomalli sisälsi ennen katselmointia myös useita, eri palvelutehtävissä tai sosiaalipalveluissa käytettäviä suunnitelman toteutumisen arvioimiseen tarkoitettuja asiakirjarakenteita. Katselmoinnissa sosiaalihuollon asiantuntijat kuitenkin näkivät, että arviointi on keskeinen osa suunnitelman laatimista eikä sitä voi irrottaa erilliseen asiakirjaan kirjattavaksi kokonaisuudeksi. Sosiaalihuollon asiakasasiakirjojen ja luokitusten asiantuntijaryhmä päätti, että saadun palautteen perusteella erillisistä suunnitelmien arvio-asiakirjarakenteista luovutaan ja arviointiin liittyvät tiedot integroidaan osaksi suunnitelmien rakenteita. 
Tätäkin ratkaisua tukee sosiaalihuoltolain muutos, jossa säädettiin, että asiakassuunnitelma sisältää asiakkaan palvelutarpeen edellyttämässä laajuudessa tiedot myös suunnitelman toteutumisen seurannasta, tavoitteiden saavuttamista ja tarpeiden uudelleen arvioinnista [13]. Myös laki sosiaalihuollon asiakasasiakirjoista ja sen esityöt korostavat arvioinnin merkitystä suunnitelmaa tehtäessä [14].

Rakenteisella tiedolla tarkoitetaan tietoa, joka kirjataan ja tallennetaan etukäteen sovitun rakenteen avulla. Tiedon rakenteisuus voi vaihdella esimerkiksi sovitun otsikon alle kirjattavasta vapaasta tekstistä tietyllä koodilla kirjaamiseen. Tiedon rakenteisuus mahdollistaa tiedon automaattista käsittelyä $[15,16]$. Katselmointipalautteen perusteella useiden asiakirjojen rakenteisuutta vähennettiin ja mahdollisuutta narratiiviseen dokumentointiin lisättiin. Seuraavassa luvussa pohditaan rakenteisuuden vähentämistä tarkemmin.

Vaikka katselmointipalaute johti merkittäviin muutoksiin asiakirjarakenne- ja jopa tietomallitasolla, niin kuitenkin iso osa saadusta palautteesta oli myös sellaista, jonka perusteella asiakirjarakenteisiin ei tehty muutoksia. Suurin osa muutoksiin johtamattomasta palautteesta oli sellaista, josta kävi selkeästi ilmi, että palautteen kohteena oleva sisältö tai rakenne oli ymmärretty väärin. Esimerkiksi kaikki palautteenantajat eivät olleet ymmärtäneet pakollisuuden ja toistuvuuden merkityksiä tai sitä, kuinka tiedot jäsentyvät ja kuinka eri otsikoiden ja kenttien nimien on suunniteltu näkyvän asiakastietojärjestelmässä. Myöskään palautetta, jossa kritisoitiin tiettyä ratkaisua ilman mistään ilmeneviä perusteluja tai parannusehdotusta, ei yleensä voitu ottaa huomioon. Sellainen palaute, joka oli ristiriidassa vallitsevan lainsäädännön kanssa, ei myöskään johtanut muutoksiin.

Excel-muotoon mallinnetut asiakirjasisällöt voivat olla vaikeaselkoisia ilman kunnollista ohjeistusta ja perehtymistä. Osa palautteesta olikin palautetta exceltaulukoiden vaikealukuisuudesta. Palautteessa saatettiin todeta suoraan, että rakenteita on vaikea hahmottaa, eikä tämän takia kommentoitavaa ole. Katselmoitavan materiaalin tarjoaminen katselmoijien saataville helpompikäyttöisessä muodossa olisi todennäköisesti vaikuttanut palautteeseen. Asiakirjasisällöistä olisi voitu esittää esimerkiksi asiakastietojärjestelmää jäljittelevien käyttöliittymien avulla. Tällainen tapa olisi ollut katselmoijille helpommin ymmärrettävä ja hahmotettava, jolloin palautteessakin olisi pystytty keskittymään oleellisiin sisältöihin.

\section{Pohdinta}

Sosiaalihuollon asiakastietomalli on tietokentiltään laaja ja sisäisiltä suhteiltaan kompleksinen kokonaisuus, jonka katselmointi ja katselmoinnista saatujen tulosten analysointi vei useita vuosia. Näiden vuosien aikana myös sosiaalihuollon toimintaympäristö muuttui ja toimialaa sääntelevässä lainsäädännössä tapahtui lyhyessä ajassa useita suuria muutoksia. Vaikuttaisi siltä, että asiakastietomalli on kasvanut rakenteeltaan niin suureksi, että sen ylläpito ja kehittäminen yhtenä harmonisoituna kokonaisuutena on nykyisillä resursseilla liian työlästä. Tietomallissa on tarpeen voida priorisoida yksittäisiä kehittämisalueita toisten osien edelle ja siirryttävä astetta ketterämpään kehittämiseen, jotta asiakirjarakenteita käyttöönotettaessa ne olisivat ajan tasalla.

Johdannossa todettiin, että tietomallin suunnittelun tavoitteena on luoda yhteinen näkemys sosiaalihuollon keskeisestä tietopääomasta. Tehtävä on haastava, koska Tieto- ja viestintäteknologian käyttö sosiaalihuollossa 2014 -selvityksen tulokset osoittavat, että sosiaalihuollon organisaatioiden käyttämien tietojärjestelmien rakenteet eivät ole keskenään yhtenäisiä eikä laajaa tahtotilaa yhtenäisyyteen toimialalla ilmene [17]. Saatu katselmointipalautekin herätti kysymyksen, voidaanko konsensus sosiaalihuollon keskeisestä tietopääomasta kaikilta osin löytää. Toimintaympäristöt ja toimintakäytännöt, ja siten myös tiedon ja dokumentoinnin tarpeet vaihtelevat jopa toimintayksiköittäin. Myös heterogeeninen asiakaskunta vaikuttaa tietotarpeiden kirjavuuteen. Katselmoinnista noussut esimerkki tästä on erityisesti päihdehuolto, jossa asiakkaiden tuen tarpeet ja ongelmien syvyys sekä palveluntuottajien näihin tarjoamat auttamisen tavat vaihtelevat suuresti. Tämä heijastui katselmoinnissa hyvin erilaisina tietotarpeina ja ristiriitaisena palautteena. Nähtäväksi jää, kuinka 
paljon Sipilän hallituksen käynnistämä sote- ja maakuntauudistus yhtenäistää sosiaalihuollon toimintatapoja ja sosiaalipalvelujen tuottamistapoja.

Hyvin erilaisiin asiakastilanteisiin kehitettyjen asiakirjarakenteiden riskinä on niiden laajuus ja se, että ammattilaiset kokevat velvollisuudekseen tallentaa kaikki mahdolliset tiedot, sellaisetkin jotka eivät ole asiakkuuden kannalta välttämättömiä. Asiakastyön dokumentoinnin tulisi jatkossakin säilyä välineellisenä, tiedonmuodostusta tukevana, eikä kilpailla sosiaalityön perustehtävän kanssa [11].

Asiakirjarakenteiden käyttämisen tueksi tarvitaan koulutusta, jotta sosiaalihuollon ammattilaiset rohkaistuvat omissa työyhteisöissään entistä enemmän analysoimaan, keskustelemaan ja etsimään yhteisymmärrystä siitä mitä erilaisissa asiakastilanteessa tarkoittaa sosiaalihuollon järjestämisen, suunnittelun, toteuttamisen, seurannan ja valvonnan kannalta tarpeelliset ja riittävät tiedot. Sote-tieto hyötykäyttöön -strategian mukaan sosiaali- ja terveydenhuollon ammattilaisten perus-, jatko-, täydennys- ja työpaikkakoulutukseen tulee sisällyttää tiedonhallinnan, tietosuojan, tietoturvan ja tietojärjestelmien käyttöön liittyviä opintoja [18]. Sosiaalihuollossa koulutustarpeeseen vastataan muun muassa Kansa-koulu -hankkeen avulla, joka tukee sosiaalihuolIon asiakasasiakirjalain toimeenpanoa. Hanke koostuu kahdesta toisiinsa limittyvästä kehittämiskokonaisuudesta: toiminta- ja tietomääritysten toimeenpanosta ja kirjaamisosaamisen kehittämisestä. [19]

Artikkelissa on yhtenä keskeisistä tuloksista raportoitu asiakirjojen rakenteisuuden vähentäminen saadun palautteen perusteella. Analyysi vahvistaa KuusistoNiemen väitöskirjassa esittämiä havaintoja siitä, että tiedon mallintamisen ja rakenteistamisen merkitys on sosiaalihuollossa ymmärretty varsin hitaasti ja, että näkemykset asiakastyössä syntyvän tiedon rakenteistamisen laajuudesta vaihtelevat. Analyysin perusteella voidaan toisaalta todeta, ettei tiedon suuri rakenteisuusaste toimi sosiaalihuollon kaikissa tilanteissa. Myös terveydenhuollossa saadut tutkimustulokset viittaavat siihen, että optimaalinen kompromissi vapaan tekstin ja rakenteisen tiedon välillä riippuu merkittävästi tiedon käyttötarkoituksesta. Rakenteistaminen parantaa tie- don hyödynnettävyyttä ja kattavuutta, eivätkä hyödynnettävyysedut tule pelkästään koneellisesta käytöstä, vaan myös ihmisen kannalta tietty määrä rakenteisuutta helpottaa tiedon hyödyntämistä. Narratiivisen tiedon ominaista käyttöaluetta terveydenhuollossa tehtyjen havaintojen mukaan ovat vaikeasti rakenteistettavissa olevat pohdintojen ja ajatusprosessien kuvaamiset. [20] Tällaista tietoa on jatkossakin tarve kuvata myös sosiaalihuollon asiakirjoissa. Sosiaalityö on ihmisten kanssa tehtävää työtä, jossa kohteet ovat monimuotoisia ja usein vaikeasti hahmotettavia. Ihmisten ongelmien ja tilanteiden kuvaamista ja niiden arviointia sosiaalityön keinoin ei ole mahdollista tehdä pelkin numeroin tai luokituksin. Narratiivisen tiedon merkitys tulee tuskin väistymään koskaan, mutta rakenteista tietoa tarvitaan tukemaan narratiivista tietoa ja kasvattamaan sosiaalihuollon tietopääomaa.

Asiakirjarakenteiden suunnittelu on tasapainottelua riittävän ja liiallisen rakenteisuuden välillä. Tehdyn analyysin perusteella rakenteisuuden vähentäminen ja siihen liittyvät näkökulmat vaikuttavat perustelluilta ja pikemminkin asiakirjojen ylirakenteistamisen purkamiselta kuin vanhan dokumentointiperinteen palauttamiselta. Osittain voi kuitenkin olla kyse myös sosiaalihuolIon ammattilaisten nykyisestä valmiudesta asiakirjojen rakenteisuuteen. Nähtäväksi jää, haluavatko sosiaalihuollon ammattilaiset tulevaisuudessa vähitellen kasvattaa asiakirjojen rakenteisuuden määrää. Toivottavasti tiedon mallintamisen ja rakenteistamisen merkitys sosiaalihuollossa avautuu myös sitä kautta, että sosiaalihuollon tietotuotanto tulevaisuudessa liittyy entistä kiinteämmin asiakastyöhön ja palvelutoimintaan läpi koko tiedonhallinnan prosessin [10].

Vaikka sekä tutkimus että kokemus puoltavat sitä, että tietorakenteiden ja -sisältöjen mallinnus pitäisi tapahtua substanssiasiantuntijoiden kanssa yhteistyössä, niin käytännössä sen toteuttaminen voi olla todella haastavaa. Julkisuudessa on käsitelty paljonkin sosiaalihuollon ammattilaisten kuormittavia työolosuhteita. Myös sosiaalihuollon asiakasasiakirjojen ja luokitusten asiantuntijoille tehty pieni kysely vahvisti käsitystä siitä, että vaikka tietorakenteiden kehittämistyötä pidetään hyvin tärkeänä, niin sen sovittaminen asiakastyön arkeen on haastavaa. Jatkossa tuleekin vielä entistä tarkemmin 
miettiä uusia keinoja sosiaalihuollon ammattilaisten osallistamiseksi.

Asiakastietomallin kehittäminen yhteistyössä sosiaalihuollon ammattilaisten kanssa on antoisaa ja palkitsevaa ja se tulee osaltaan myös helpottamaan asiakasasiakirjarakenteiden käyttöönottoa. Tietomalli on kuitenkin vain yksi osa ammattilaisten käytössä olevaa tietojärjestelmää. Terveydenhuollossa tehtyjen havaintojen mukaan rakenteet ovat yksi, mutta eivät ainoa tietojärjestelmien käytettävyyteen vaikuttava tekijä. Rakenteiden ja käyttöliittymien sidokset ovat niin tiukkoja, että niiden vaikutus ei välttämättä ole aina erotettavissa toisistaan. [20] Sosiaalihuollon asiakastietomalliin tehdyt panostukset saattavat osittain valua hukkaan mikäli tietojärjestelmien käytettävyyttä ja muita ominaisuuksia ei myös kehitetä yhdessä sosiaalihuollon ammattilaisten kanssa. Sosiaali- ja terveysministeriön (STM) Sote-tieto hyötykäyttöön -strategian mukaan asiakastietojärjestelmien kehittämisessä ja uudistamisessa tuleekin parantaa yhteistyötä käyttäjien kanssa, jotta tietojärjestelmät jatkossa vastaisivat aiempaa paremmin käyttäjien ja palvelujärjestelmän tarpeisiin [18].

\section{Lähteet}

[1] Ailio E, Kärki J. Sosiaalihuollon asiakastietomalli. FinJeHeW 2013;5(2-3)40-49.

[2] Rötsä M, Berglind H, Huovila M, Hyppönen K, Peksiev T, Mykkänen J. Sosiaalihuollon valtakunnallisten tietojärjestelmäpalvelujen ja määrämuotoisen kirjaamisen toimeenpanohanke (Kansa-hanke): Hankesuunnitelma vuosille 2016-2020. Terveyden ja hyvinvoinnin laitos; 2016. Saatavilla: http://urn.fi/URN:ISBN:978-952302-660-5 (Viitattu 7.7.2016)

[3] Granholm C. Social Work in Digital Transfer - blending services for next generation. Academic Dissertation. Helsinki: University of Helsinki; 2016.

[4] Smedberg J. Asiakaslähtöisyyden merkitys tietojärjestelmien kehittämisessä - tarkastelu sosiaalihuollon kokonaisarkkitehtuurin kontekstissa. Tampereen yliopisto, Informaatiotieteiden yksikkö. Pro gradu tutkielma. Tampere: Tampereen yliopisto; 2014.
[5] Kagle JD, Kopels S. Social Work Record. 3rd edition. Long Grove, IL: Waveland Press; 2008.

[6] Räsänen J-M. Producing Norm Talk of Fact-based Case Recording in Interviews With Emergency Social Workers. Qualitative Social Work 11/ 2012 s. 6-22.

[7] Kuronen M, Isomäki H. Parempaa sosiaalityötä vai teknologian orjuutta? - ihmisläheisen tietojärjestelmien kehittämisen mahdollisuudet sosiaalityössä. Teoksessa: Pohjola A, Kääriäinen A, Kuusisto-Niemi S. (toim.) Sosiaalityö, tieto ja teknologia s. 185-209. Juva: PSkustannus; 2010.

[8] Wastell D, White S, Broadhurst K, Hall C, Peckover S. The chiasmus of design: paradoxical outcomes in the egovernment reform of uk children's services. ECIS 2009 Proceedings. Paper 397.

[9] Gillingham P, Graham T. Designing electronic information systems for the future: Social workers and the challenge of New Public Management. Crit Soc Policy 2016;36(2):187-204.

[10] Kuusisto-Niemi S. Tiedonhallinta sosiaalihuollossa. Tiedonhallinnan paradigma opetuksen ja tutkimuksen perustana. Itä-Suomen yliopisto, Yhteiskuntatieteiden ja kauppatieteiden tiedekunta. Väitöskirja. Itä-Suomen yliopisto; 2016. Saatavilla: http://urn.fi/URN:ISBN:978952-61-2279-3 (Viitattu 27.12.2016)

[11] Kääriäinen A. Sosiaalityön dokumentointi: Suhde tietoon ja toimintaan. Teoksessa: Törrönen $M$ et al. (toim.) Vastavuoroinen sosiaalityö s. 189-197. Gaudeamus; 2016.

[12] Tieto Oyj THL:n toimeksiannosta: ASKO Sosiaalihuollon asiakastietomallin mukaisten asiakasasiakirjojen sisällön katselmointi Loppuraportti vaiheet 1 ja 2 . Terveyden ja hyvinvoinnin laitos; 2015. Saatavilla: http://www.thl.fi/attachments/tiedonhallinta/asko_lop puraportti.pdf (Viitattu 7.7.2016)

[13] Sosiaalihuoltolaki. Saatavilla: http://www.finlex.fi/fi/laki/ajantasa/2014/20141301?s earch\%5Btype\%5D=pika\&search\%5Bpika\%5D=sosiaalih uoltolaki (Viitattu 7.7.2016)

[14] Laki sosiaalihuollon asiakasasiakirjoista: http://www.finlex.fi/fi/laki/ajantasa/2015/20150254?s 
earch\%5Btype\%5D=pika\&search\%5Bpika\%5D=laki\%20s osiaalihuollon\%20asiakasasiakirjoista (Viitattu 7.7.2016)

[15] Virkkunen $H$, Mäkelä-Bengs $P$, Vuokko (toim.) Terveydenhuollon rakenteisen kirjaamisen opas Osa I Keskeisten kertomusrakenteiden kirjaaminen sähköiseen potilaskertomukseen, versio 2015. Terveyden ja hyvinvoinnin $\quad 2015 . \quad$ laitos; Saatavilla: http://urn.fi/URN:ISBN:978-952-302-479-3 (Viitattu 7.7.2016)

[16] Hyppönen, H, Vuokko R, Doupi P, Mäkelä-Bengs, $P$ (toim.) Sähköisen potilaskertomuksen rakenteistaminen - Menetelmät, arviointikäytännöt ja vaikutukset. Terveyden ja hyvinvoinnin laitos; 2014. Saatavilla: http://urn.fi/URN:ISBN:978-952-302-381-9 (Viitattu 7.7.2016)

[17] Kärki J, Ryhänen M. Tieto- ja viestintäteknologian käyttö sosiaalihuollossa vuonna 2014. Terveyden ja hyvinvoinnin laitos; $2015 . \quad$ Saatavilla: http://urn.fi/URN:ISBN:978-952-302-593-6 (Viitattu 7.7.2016)
[18] Sosiaali- ja terveysministeriö: Tieto hyvinvoinnin ja uudistuvien palvelujen tukena, Sote-tieto hyötykäyttöön - strategia 2020. Sosiaali- ja terveysministeriö; 2014. Saatavilla: http://urn.fi/URN:ISBN:978-952-003548-8 (Viitattu 7.7.2016)

[19] Kaakkois-Suomen sosiaalialan osaamiskeskus Oy Socom et al. Kansa-koulu Sosiaalihuollon asiakasasiakirjalain toimeenpano, Hankesuunnitelma. 2015. Saatavilla: http://www.socom.fi/wpcontent/uploads/2015/08/Kansa-kouluhankesuunnitelma.pdf (Viitattu 7.7.2016)

[20] Forsvik H, Voipio V. Tulokset kliinisen työn näkökulmasta. Teoksessa: Hyppönen, $H$, Vuokko R, Doupi $P$, Mäkelä-Bengs, P (toim.) Sähköisen potilaskertomuksen rakenteistaminen - Menetelmät, arviointikäytännöt ja vaikutukset. Terveyden ja hyvinvoinnin laitos; 2014. Saatavilla: http://urn.fi/URN:ISBN:978-952-302-381-9 (Viitattu 7.7.2016) 